\title{
Information Management and Organisational Performance: A Review of Literature
}

\author{
Opoku, Mustapha Osman
}

Catholic University College of Ghana, Adom, Kwame (PhD), University of Ghana

(Corresponding author) Yawoaman2004@yahoo.co.uk

\author{
Doi:10.5901/mjss.2015.v6n6s1p62
}

\begin{abstract}
Studies have demonstrated that one of the world's most vital resources is information as it is required to solve problems and make decisions affecting both the present and the future. There is enough evidence to explain that the degree of success enjoyed by an organisation and its members depends largely on how well information is managed. The purpose of this paper is to present review of some major studies on information management in order to provide an understanding of existing knowledge, practices, identify the gaps and make a case for further studies in the area of information management. The research papers were generated from renowned journals such as Emerald, Science direct, IJRIC South African Journal of Information Management, and many others. The review indicates that information management is multi-disciplinary that combines skills and resources from many fields. The review also establishes that information management is distinctively different from information technology. While investment in information technology has not yielded corresponding impact on organisational performance, investment in information management has positively influenced organisational performance. Lack of resources such as funds, human resource, and infrastructure and managerial support have been identified as the main hindrance to information management programmes. The review discloses that formulation of policies and strategies that are in line with the organisational goals and strategies, the adoption of appropriate technologies and top management support are necessary for effective information management. Lastly, the review has shown that the technical aspect of information management has been over-emphasized but equal attention has not been paid to the management aspect. It is, therefore, recommended that researchers' attention need to be directed to information management.
\end{abstract}

Keywords: Information management, information technology, organisational performance

\section{Introduction}

\subsection{Rationale for the Review}

The world's economic trends in business require organisations to respond quickly to demand and opportunities through competition and continuous expansion of domestic and international markets and by being innovative as well. This requires organisational members to move beyond and achieve higher frontiers which are achievable only by having the right information. Studies have shown that one of the world's most important resources is information since it is needed to solve problems and make decisions affecting both the present and the future. There is enough evidence to explain that the degree of success enjoyed by an organisation and its members depends largely on how well information is managed. Information as a resource of organisations has been defined differently by different authors. The view of O' Brien \& Marakas (2008) and Laudon \& Laudon (2010) is that, information is data that have been processed into a form that is meaningful and useful to the recipient and has a real or perceived value and can cause a change in decision making. Robek, Brown, and Stephens (1995) describe it as any intelligence, which can be communicated in either graphic form or alphanumeric character, which include records, documents, data and files created and maintained by organisations.

As a vital resource, information plays very important roles in the life of every organisation and therefore its management has attracted the attention of practitioners and academics as well.

Many studies have been conducted in the area of information management and the available literature indicates that there are controversies regarding the title, content, and the processes involved in information management (Anand, Manz, \& Glick, 1988), which need to be addressed.

\subsection{Purpose of the Review}

A well-informed society is a vibrant and prosperous one. Implicitly, organisations whose members are well informed can 
achieve higher performance. Improving information management practices has therefore attracted the attention of many researchers. This paper sought to review some studies on information management in order to provide an understanding of existing knowledge and practices, identify the gaps and make a case for further studies in the area of information management.

\subsection{Methodology and Structure of the Review}

Information management draws its ideas and concepts from different disciplines. This review summarises the literature, which mainly are research findings in the discipline contributing to understanding the practice of information management in organisations. Information management, to some extent, is organisational and or cultural specific. However, global views and evaluations from all over the world are likely to influence other practices, policies and paradigms. This review, therefore, includes literature from the world's renowned journals like Emerald, Science direct, IJRIC, South African Journal of Information Management, and many others. Searches for relevant literature were done using search engines such as goggle scholar and others. The review covers the concept of information management, empirical evidence and conclusion.

\section{The Concept of Information Management}

Information management (IM) is the collection and management of information from one or more sources and the distribution of that information to those who have right to it (Robertson, 2005). The management as used in this context means the organization of and control over the structure, the processes and the delivery of information. Henczel, (2000) and Ravi, (2011) consider information management as the systematic imaginative and responsible management of information in order to create and use information that will contribute strategically to the achievement of an organisation's goals and make sure that groups and individuals have efficient access to and make effective use of the information they need to do their work and to develop themselves. Information management is theorized to involve a continuous cycle of closely related activities such as identification of informational needs, acquisition and creation of information, analysis and interpretation of information, organisation and storage of information, information access and dissemination and information use (Henczel, 2000; Robertson, 2005; Ravi, 2011).

Identification of informational needs involves realization of the pivotal roles of information in the achievement of organisational goals and strategically plan for it. Maceviciute and Wilson (2002) define information management to include developing and implementing information policy and strategy; data creation and management; processing, storage and information delivery; and information usage. Ravi (2011) indicates that effective information management combines technological innovations and intelligent processes to deliver cost effective information compliance and data protection. This suggests using the information technology and other accessories to create, organize, store, process and distribute information to those who have to use them for the achievement of organisational objectives.

In support of this, Robertson (2005) opines that information management can be defined from both technical and management points of view. Technically, information management includes all systems and processes such as web content management, document management, records management, digital asset management, learning management systems, enterprise search (the technical infrastructure) used to support the information management programmes (Reddy, Srinivasu, Rikkula, \& Rao, 2009). From the management point of view, Robertson (2005) views information management as the organisational, social, cultural and strategic factors that must be considered in order to improve information in organisations. This stresses the importance of managerial and technical roles in any effective information management programme. It can be explained that information management is a corporate responsibility that needs to be addressed and followed from the top level managers to the lower level employees to ensure effective and efficient creation, storage, processing and distribution of information to support operations and other decision making activities in an organisation (Reddy, Srinivasu, Rikkula, \& Rao, 2009).

The available literature on information management (Henczel, 2000; Ravi 2011; Saloojee, Groenewald, \& du Toit, 2007; Weintraub, Owens, \& Jedinak, 2013) have underscored the importance of information management in the achievement of organisational goals. The strategic role of information management in giving a company major advantages over the competition it faces in the local and global marketplace cannot be overemphasised. Creating strategic information requires that the manager understands the entire firm and its relationships with external agents in the environment such as suppliers, consumers, workers, and rivals. According to Stair and Reynolds, (2006), O' Brien and Marakas (2008), and Laudon and Laudon, (2010), a firm can succeed if it can develop strategies to confront five competitive forces that shape the structure of its industry. The compective forces as proposed by Michael Porter are; 
competitors' rivalry, threat of new competitors, customers' bargaining power, the availability of substitute products or services and suppliers' bargaining power (Meriel, 2010).

It is argued that businesses can counter the threats of competitive forces that they face by implementing five basic competitive strategies provided by information management, which include cost leadership, product differentiation, innovation, growth and alliances (O' Brien \& Marakas, 2008). According to Robek, Brown and Stephens (1995), information management has the following objectives;

- To furnish accurate, timely and complete information for effective decision making in the management and operation of an organisation.

- To provide information and records at the lowest possible cost.

- To render maximum service to the user of the records and

- To dispose of records that are no longer needed in the organisation.

In addition to these, information management has the objective of processing recorded information and distributing them to all users as efficiently as possible to ensure that the value of information is identified and exploited to achieve the fullest benefits. To be able to achieve these objectives, information needs to be managed like all other resources. Many including Henczel (2000), Saloojee, Groenewald and du Toit (2007), Ravi (2011), Weintraub, Owens and Jedinak (2013) argue that the main idea underlying information management is that as organisations purposefully and systematically manage their other resources such as financial and human resources, they should do likewise for their information resources and processes. That is to say, all the classical functions of managing organisational resources must be applied to information management as well. These managerial functions include defining informational goals, providing leadership, developing informational policies, allocating appropriate resources, training staff, and evaluating information and providing feedback (Robertson, 2005). Organisations must, therefore, be responsible for holding their employees accountable to capture, manage, store, share, preserve, and deliver information appropriately and responsibly. Literature indicates that information management is very important in the achievement of organisational objectives (Otike, 2010). The issues of concern are "what is the state of information management research?" "Is there a higher level of academic discussion, evaluation and control to ensure that quality information is available to enhance higher performance in organisations?" "What is the direction of information management research?" These and other concerns necessitated the review of literature in this area.

\section{Review of Literature on Information Management}

The review intended to bring to out information management and its influence on organisational performance. Various studies on information management and its impact on organisational performance have been reviewed. The review is based on these areas namely, the evolution of information management, factors influencing information management, challenges facing information management practices and the influence of information management on organisational performance.

\subsection{Evolution of Information Management}

Trauth (1989) extensively examined the origin and evolution of the concept of information management by reviewing information management literature. The review examined and defined information management along the following dimensions: disciplinary perspective, management scope, societal sector, vocabulary and goals. The study indicated that the concept of information management evolved in three different sectors of the information processing community, namely data management, records management and data processing management, which hardly interact. It was observed that information should be recognized as a valuable entity and it should be independent of the technology that manipulates it. The review stressed the need to maintain a global view of corporate data, repositioning of the information management officer at a high level in the corporate hierarchy to integrate both information and information technology and that the future success of information management will depend on its ability to incorporate end users into the information management framework. The findings from the review indicate that researchers disagree on the meaning, discipline and dimensions of information management and that information management is a different entity which must be separated from information technology. The involvement of the top level managers was also considered to be very important in any effective and efficient information management programme.

Earl (1989) categorises the evolution of information management into traditional era and technical era. The traditional era covers the period in which information was managed manually, using human brains and hands, cabinets, 
papers and pen or pencils. On the other hand, the technological era is the period in which information technology is introduced into the management of information programmes to address some of the inherent problems of the manual system. The study observed that effective information management involves three activities: planning methods, control procedures and organisational arrangements. This stresses the importance of management functions (planning, organising, leading and controlling) in any information management programmes.

A study by Maceviciute and Wilson (2002) reveals the changes that have occurred in information management research from 1989 to 2000. The authors reviewed the various articles published in renowned journals on the subject and the following issues came to light:

- empirical research in the areas of economics, management, organisational theory, information systems, library and information science have significant influence on information management research.

- researchers and practitioners have divergent views on the content and the scope of information management.

- information management is changing in the same direction as human factors, organisational environment and culture, users involvement and satisfaction are gaining more attention than previously.

The study pointed out that the new areas of concern regarding information management are: economics of information and the adoption of technology, therefore there is the need for managers/practitioners to develop policies and strategies to guide the operations of information management. The review supports the fact that information management is a multidisciplinary concept and management involvement is very crucial.

Sebina (2007) set out to examine the changes that information management in Africa has undergone. It was found that most African countries are adopting freedom of information (FOI) legislation with the presumption that there exists a good information infrastructure and management is to guarantee access to information. In examining some studies done in some African countries and the United Kingdom, it emerged that information management has been neglected in Africa. The review argues that a good information management that supports businesses and corporate memory is a prerequisite for FOI legislation and therefore advised countries such as Botswana, Malawi and Ghana that are yet to adopt the legislation to consider a sound information management as a tool necessary for successful implementation of the FOI legislation. The study indicated the need for infrastructure (technology) and management involvement in information management activities. The review re-emphasizes the importance of information management in achieving good governance.

Supporting the need for technology in information management, Kulcu (2009) used the survey method to evaluate the new aspect of records management with the introduction of technology. It came to light that developing official communication flow with the use of technology is a must, and there is however the need for organisations to meet legal and administrative requirements in relation to electronic records management application.

A similar review was conducted by Stamoulis, Gouscos, Georgiadia and Martako (2001) on public information management for effective e-government services. The study aimed at investigating the new public information management philosophy and the business strategy followed. It emerged from the study that a clear articulating policies and strategies to support information management programmes are necessary to deploying the digital interface that will provide customers with high quality services. Two important issues emerged from this study, namely, the need for policies and strategies to regulate information management programmes and the adoption of technology as a supportive component of information management programmes.

\subsection{Factors Influencing Information Management and Challenges}

The focus of this section is to present factors influencing information management practices and the challenges as have been revealed by scientific investigation. Almutairi (2011) conducted a study on factors influencing the information management behaviour in the Kuwaiti civil service. The study sought to evaluate the impact of personal and professional factors on public sector managers' information behaviour. The result of the study identified age, education, and information system used as the key variables that make a difference in information management behaviours of managers.

A similar study was conducted by Kahraman and Cevilecan (2011) on the intelligence decision systems in enterprise information management in Turkey. The study identified intelligence technique as a new tool for information management. Intelligence technique was defined as systems that support decision making by gathering, analysing and diagnosing problems; proposing possible causes of actions as well as evaluating the proposed actions. The study emphasised that for effective information management, there is the need to integrate cross-functional strategies, and investment in information management should be guided by both intelligence techniques and business strategy and needs. 
Kalusopa and Ngulube (2012) also examined the records management practices in labour organisations in Botswana. The study which was quantitative in nature used a survey strategy to gather responses from 45 respondents. The study acknowledges the existence of information management practices in the various organisations but they fall below the expected standard. The result shows that the information management programmes are faced with many problems cutting across all the processes namely, creating, storing, processing and distribution. The outcome of the study reiterates the need for policies and strategies in information management to ensure effective performance.

Tungare (2007) studied the evolution of information management practices from users' perspectives. The review established that the major concerns of information management practices include information overload and information fragmentation. Information overload was defined as a situation where information processing and demand on individuals/organisations exceed the capacity and competency and the time needed for such processing. Information fragmentation, according to the review, is a situation where data are in different format, stored and distributed across multiple devices and locations using different applications for manipulation. It was established from the review that even though the technology has eased the processing of recording, creating, receiving, storing and disseminating, managing and using them sensibly is difficult. The amount of information generated by individuals/organisations can only increase, but organisational resources have remained constant. The situation poses a very difficult future for information workers whose job requires them to stay informed.

Robertson (2005) did some work on the effective information management and develop certain principles that are crucial and considered as critical success factors for information management projects. The review outlines the major challenges in information management programmes in contemporary organisations including: large number of disparate information management systems, which is hardly coordinated, lack of clear policies and guidelines on information management programmes as well as lack of top management's support; the human and other physical resources needed for effective information management are also lacking. These challenges have led to poor quality, inconsistency, duplication and outdated information. To address some of these issues, the study proposes that information management programmes should recognise the complexity of needs and plan to address these needs. Information management projects should deliver on tangible and visible benefits, and there is the need for active participation of all staff of the organisation and strong leadership. Lastly, information management programmes should be developed based on sound policies and strategies that are derived from the organisational strategy.

A similar study was conducted by Iron Mountain to assess the information management compliance benchmark, compare information management programmes across five best practice areas. It emerged from the study that there is a significant improvement in information management practices but there are some challenges in the areas of policies and procedures that need to be addressed. On electronic records management, the study points out that there is improvement in policy development but most organisations have not being putting them into action. Writing on the best practices of information management, the study identified five main areas namely: policies and procedures, retention, index and access, privacy and disposal, and audit and accountability. Regarding how information management is evolving, the survey gave the following specifics: $94 \%$ of the organisations sampled are investing more in information management, and $72 \%$ do not have a strategic plan for information management. It also came to light that $80 \%$ of the organisations do have a formal policy, only $37 \%$ did indicate that the policies are consistently applied (Ebbighausen, 2011). The results of the survey indicate that much have been done on investment and formulation of policy regarding information management. However, the policies are not well implemented and in some cases strategic plan on information management is lacking.

Maitland, Tchovakeu and Tapia (2009) set out to study organisational barriers to coordination arising specifically from information management and information technology issues. It emerged from the study that in dealing with information management it requires a higher level of organisational change as compared with information technology. This suggests that information management issues are different from those of information technology and the former require the attention and involvement of all the organisational members, especially the top level managers. Burns, Ferris, \& Liatsopoulos (2009) conducted a review to ascertain the awareness on the need for effective information management practices and to identify the challenges confronting many African countries in that regard. The study emphatically indicates that the various poverty reduction strategies being implemented by the various African governments will be fruitless if they do not include some policies and strategies that address governments' records. Using specific examples from some African countries, the study identifies the following challenges: problem associated with the colonial administrators' failure to create an appropriate record/information management scheme; lack of funding, old and insufficient infrastructure, lack of staff with appropriate training on digital divide. The study argued that until these issues are addressed appropriately no significant impact will be made in Africa in terms of development since effective information management is an integral part of any country's rebuilding process. 


\subsection{Information Management and Organisational Performance}

The relationship between information as a resource and performance of organisation cannot be over emphasised. Many including Esterhuizen, Schutte and Du Toit (2012) have studied how information management framework impacts on innovation capacity. The study selected five industry and subject theory experts to evaluate the applicability and suitability of the framework. It was observed that organisations can use information/knowledge management tools to create innovational capacity and growth, which may lead to high performance of organisations.

Meriel (2010) used various ideas, concepts and research findings that have practical relevance for personal information to evaluate how individuals typically organize their information. The results of the study indicate that information that is organised may serve three distinct purposes, namely easy records retrieval, reminds users on tasks that need to be done and represents the users' understanding of information items and how they relate to each other. The review further stresses the pivotal and vital role played by information management in improving organisational performance.

In a study to examine the impact of information management investment value on organisational performance, Stewart, Coulson and Wilson, (2007) argue that there are many studies that have established that investment in technology has contributed significantly to the growth of output in the United States but profitability and productivity have not come as a result of investment in information technology. The study contends that many studies to investigate how investment in information technology (IT) will lead to positive outcome, maintain that several factors account for organisational performance including a firm's strategic advantage and innovative technology. This suggests that investment in IT has indirect impact on organisational performance.

In an effort to address the question of what motivate(s) organisations to invest in information management, Robeck, Brown and Stephens (1995) propose ten reasons including the need to:

1. control the creation and growth of records

2. reduce operating cost managing information

3. improve efficiency and productivity

4. assimilate new records management technologies

5. ensure regulatory compliance

6. minimize legislation risk

7. safeguard vital information

8. support better management decision making

9. preserve the corporate memory and lastly

10. foster professionalism in running the business.

These reasons are important elements to achieving organisational success, hence the importance of information management in organisations.

A study by Stiroh (2001) to evaluate the relationship between investment in information managed by technology and productivity pay offs in the United States industries indicates that there is a robust evidence of a correlation between the productivity acceleration and the intensive use of information technology (IT) in the late 1990s. In a similar study to evaluate the high increase in information technology investment in the 1990s by Doms (2004), it emerged that the increase may be attributed to the fall in the prices of information technology goods, but not necessarily the fact that IT can boost productivity, which contradicts the finding of Stiroh (2001).

Love and Irani (2004) conducted a study to evaluate IT investment cost and benefit that organisations have experienced due to IT implementation. The study used survey method to collect data from 126 construction firms, which were Small and Medium scale Enterprises (SMEs). Three key findings emerged from the study namely: that different types of organisations invest differently in IT, investment in IT was not influenced by the size of the organisation and lack of strategic vision served as a challenge in justifying IT investment. The study concluded that the ability of construction SMEs to compete depends, to alarge extent, on the role of managers, tangible investment in intellectual capital, investment in ICT and strategic capacity.

A survey carried out by Information Management Solution on the facts about information management reveals that $15 \%$ of organisational revenue is spent on creation, management and distribution of information, $60 \%$ of employees' time is spent on working with information, $75 \%$ of records are still kept in paper form and $65 \%$ of workers' time spent looking for information. The study emphasizes that managing information as an important resource will help to improve organisational performance by controlling the creation and growth of information, reducing operating cost, improving efficiency and productivity and safeguarding vital information. All these will eventually give organisations competitive advantage (www.southwest.solution). 
A study by Weintraub, Owens and Jedinak (2013) observes that the information management landscape is wide and diverse and organisations depend on many information sources to make key decisions. The survey indicates that only $13 \%$ of the respondents have a formal information management strategy and $72 \%$ have improved compliance with the laws and regulations/policies. On the benefit of information management, $87 \%$ of the respondents indicated that it has reduced cost and improved efficiency and $68 \%$ said it has helped to increase revenue. It review suggests that organisations should begin to develop information management strategies that have a vision of harmonizing the different systems into a common system and this will result in strategic/competitive advantage.

Reddy, Srinivasu, Rikkula and Rao (2009) studied how Management Information Systems (MIS) has helped managers in decision making and identified the following key performance benefits: effective and efficient coordination between departments, quick and reliable referencing, access to relevant data and documents, reduction in labour cost and assisting in the day-to-day operations of the organisation such as accounting, stock control and many others. The result from the study indicates that MIS, which many researchers like Davis equate to information management, helps organisations to save time, cost and labour, which eventually improve organisational performance.

Saloojee, Groenewald and du Toit (2007) set out to evaluate the business value of information management and its investment benefits. The study established that information management creates indirect business value but has direct business cost, thus making the assessment of information management investment very difficult. It was identified that there are three important information management initiatives, which are business objectives, implementation and business outcome. This means that the business objectives look at the organisational goals and objectives that the information management initiative addresses using technical, business design and operations to implement the initiatives and evaluating how information management is used to achieve objectives. The result of the study indicates that for the business value of information management and its investment benefits to be realized, information management strategies should be aligned with the overall strategy of the organisation.

\section{Conclusion and Recommendations}

The review indicates that information management has moved from the traditional era where information related issues were handled manually to technological era where information technology is used, which has improved information management activities beyond expectation. The literature review has also shown that information management is a multidisciplinary concept that combines skills and resources from many fields of study including economics, management, organisational theory, information systems, library and information science (Maceviciute \& Wilson, 2002). For best practices regarding information management, the review stresses the need for policies and strategies that are in line with the organisational goals and strategies, the adoption of appropriate technologies and support from the top level management. Again, the review has disclosed that lack of funds, human resource, infrastructure, and managerial support are the main challenges facing information management programmes in organisations.

The review indicates that information management is not the same as information technology, which may require varied investments. There are many studies that show that investment in information technology has not yielded corresponding impact on organisational performance. However, investment in information management has positively influenced organisational performance through increased efficiency, productivity and competitive advantage. Lastly, it is revealed from the literature that the managerial aspect of information management is under researched and underexplored as opposed to the technical aspect, which has received much attention. Hence, it is recommended that researchers' attention must be directed to the managerial aspect since many researchers including Trauth (1989), Robertson (2005), Kulcu (2009) claim that failure in most information management programmes are more attributed to management rather than the technology.

\section{References}

Almutairi, H. (2011). Factors affecting the information behaviour of managers in Kuwaiti civil service: a rational model. Information Research , 16.(2).

Anand, V., Manz, C. C. and Glick, W. H. (1988). An Organisational Memory Approach to Information Managemet. Academy of Managemet Review, 23.(4), 796-800.

Burns, S., Ferris, J. and Liatsopoulos, D. (2009). The Problem and Barriers of Records and Information management in Africa. SA Journal of Information Management , 1-25.

Doms, M. (2004). The Boom and Bust in Information Technology Investment. Federal Reseve Bank of San Francisco , 19 - 34.

Earl, M. J. (1989). Management Strategies for Information Technology. Mayland Avenue : Prentice Hall International (UK) Ltd Campus 400. 
Ebbighausen, H. (2011). How records and information management practices continue to evolve. North America: Iron Mountain.

Esterhuizen, D., Schutte, C. and Du Toit, A. (2012). A knowledge management framework to grow innovation capacity maturity. SA Journal of Information Management , 14 (1), Art \# 495, 10.

Henczel, S. (2000). The Information Audit as a First Step towards Effective Knowledge Management: An Opportunity for the Special Librarian. Worldwide Conference on Special Librarianship (pp. 210-226). Brighton: Special Libraries Association (SLA).

Kahraman, C., Kaya, I. and Cevikcan, E. (2011). Intelligence decision systems in enterprise information management. Journal of Enterprese Information Management (Emerald Insight) , 24 (4), 350379.

Kalusopa, T. and Ngulube, P. (2012). Record Management practices in Labour Organisations in Botswana. SA Journal of Information Management, 14 (1), Art 513, 15.

Kulcu, O. (2008). Evolution of e-records management in practices in e-government. Emerald Group Publishing Limited , $999-1009$.

Laudon, K. C., and Laudon, J. P. (2010). Management Information Systems, Managing the Digital Firm: (11th Edition). New Jeesey: Pearson Education, Inc., Upper Saddle River.

Love, P. E. and Irani, Z. (2004). An exploratory study of information technology evaluation and benefits management practices of SMEs in the construction industry. Elsevier: Information and Managment, 227 - 242.

Maceviciute, E., and Wilson, T. D. (2002). The development of the information management research area. Information Research , 7 (3).

Maitland, C., Tchovakeu, L.-M. N., and Tapia, A. H. (2009). Information management and technology issues addressed by Humanitarian Relief Coordination Bodies. 6th International ISCRAM Conference. Gothemburg, Sweden: 6th International ISCRAM Conference.

Meriel, P. (2010). Personal Information Management - Literature Review. Oxford University Computing Services: JISC- Funded Sudamith Project .

O' Brien, J. A. and Marakas, G. M. (2008). Introduction to Information Systems, (14ted.).New

York: McGraw-Hill/Irwin Companies, Inc., 1221 Avenue of the Americas.

Otike, J. (2010). The proposed freedom of information Act and its effect on access to information in the public domain in Kenya. 6th Annual International Conference, September 7 - 10, 2010. Eldoret: Moi University.

Rao, I. K. (1999). Information Management Scope, Definition, Challenges and Issues. DRTC Workshop on Information Management. Bangalore: Indian Statistical Institute.

Ravi, T. M. (2011). The Path to Information Management Nirvana. Information Management Daily .

Read-Smith, J., Ginn, M. L., and Kallaus, N. F. (2002). Records Management (7th Edition ed.). New York: Thompson Learning Inc: South-Western.

Reddy, G. S., Srinivasu, R., Rikkula, S. R., and Rao, V. S. (2009). Management Information Systems to help Managers for Providing decision making in an Organisation. International Journal of Reviews in Computing , 2076-3336.

Robek, M. F., Brown, G. F., and Stephens, D. O. (1995). Information and Records Management: Document-Based Information Systems (4th Edition ed.). New York, Columbus: Mc Graw-Hill.

Robertson, J. (2005). 10 Principles of Effective Information Management. Step Two Design pty Limited.

Saloojee, R., Groenewald, D. and du Toit, A. S. (2007). Investigating the business value of information management . South African Journal of Information Management.

Sebina, P. M. (2007). Information management in Africa to undergo a change. Access to Information Network-Africa (ATINA) .

Stair, R. M. and Reynolds, G. W. (2006). Principles of Information Systems, A Managerial Approach, (7 $7^{\text {th }}$ ed.). Boston, Massachusetts: Thomason Learning Inc.

Stamoulis, D., Gouscos, D., Georgiadis, P., and Martakos, D. (2001). Revisiting Public

Information Management for Effective e-government Services:. Information

Management and Computer Security Emerald Journals , 9 (4), 146-153.

Stewart, W., Coulson, S., and Wilson, R. (2007). Information Technology: When is it Worth the Investment. Communications of the IIMA , $7 ;(3)$.

Stiroh, K. J. (2001). Investing in Information Technology: Productivity Payoffs for U.S. Industries. Current Issues in Economics and Finance: Federal Reserve Bank of New York, 7 ; (6).

Trauth, E. M. (1989). The Evolution of Information Resource Management . Information and Management 16 , 257 - 268.

Tungare, M. (2007). Understanding the Evolution of Users' Personal Information Management Practices. Blacksburg, VA, USA:: Springer Berlin Heidelberg.

Weintraub, A., Owens, L., and Jedinak, E. (2013). The enterprise information management Barbell strengthens your information value. Cambridge M.A. USA: Forrester Research Inc.

Web resources: http://www.southwestsolution.com/markets/information-management-solutions Retrieved July 15, 2013.

\section{Works Cited}

Almutairi, H. (2011). Factors affecting the information behaviour of managers in Kuwaiti civil service: a rational model. Information Research, $16(2)$.

Anand, V., Manz, C. C., \& Glick, W. H. (1988). An Organisational Memory Approach to Information Managemet. Academy of Managemet Review, 23(4) , 796-800.

Burns, S., Ferris, J. and Liatsopoulos, D. (2009). The Problem and Barriers of Records and Information management in Africa. SA 
Journal of Information Management, 1-25.

Doms, M. (2004). The Boom and Bust in Information Technology Investment. Federal Reseve Bank of San Francisco, 19 - 34.

Earl, M. J. (1989). Management Strategies for Information Technology. Mayland Avenue : Prentice Hall International (UK) Ltd Campus 400.

Ebbighausen, H. (2011). How records and information management practices continue to evolve. North America: Iron Mountain.

Esterhuizen, D., Schutte, C. and Du Toit, A. (2012). A knowledge management framework to grow innovation capacity maturity. SA Journal of Information Management , 14 (1), Art \# 495, 10.

Henczel, S. (2000). The Information Audit as a First Step towards Effective Knowledge Management: An Opportunity for the Special Librarian. Worldwide Conference on Special Librarianship (210-226). Brighton: Special Libraries Association (SLA).

Kahraman, C., Kaya, I., and Cevikcan, E. (2011). Intelligence decision systems in enterprise information management. Journal of Enterprese Information Management (Emerald Insight), 24 (4), 350379.

Kalusopa, T., and Ngulube, P. (2012). Record Management practices in Labour Organisations in Botswana. SA Journal of Information Management, 14 (1), Art 513, 15.

Kulcu, O. (2008). Evolution of e-records management in practices in e-government. Emerald Group Publishing Limited, 999-1009.

Laudon, K. C. and Laudon, J. P. (2010). Management Information Systems, Managing the Digital Firm. (11 th ed). New Jeesey: Pearson Education, Inc., Upper Saddle River.

Love, P. E., and Irani, Z. (2004). An exploratory study of information technology evaluation and benefits management practices of SMEs in the construction industry. Elsevier: Information \& Managment, $227-242$.

Maceviciute, E., and Wilson, T. D. (2002). The development of the information management research area. Information Research, 7 (3).

Maitland, C., Tchovakeu, L.-M. N., and Tapia, A. H. (2009). Information management and technology issues Addressed by Humanitarian Relief Coordination Bodies. 6th International ISCRAM Conference. Gothemburg, Sweden: 6th International ISCRAM Conference.

Meriel, P. (2010). Personal Information Management - Literature Review. Oxford University Computing Services: JISC- Funded Sudamith Project .

O' Brien, J. A. and Marakas, G. M. (2008). Introduction to Information Systems, (14th ed). New York: McGraw-Hill//rwin Companies, Inc., 1221 Avenue of the Americas.

Otike, J. (2010). The proposed freedom of information Act and its effect on access to information in the public domain in Kenya. 6th Annual International Conference, September 7 - 10, 2010. Eldoret: Moi University.

Rao, I. K. (1999). Information Management Scope, Definition, Challenges and Issues. DRTC Workshop on Information Management. Bangalore: Indian Statistical Institute.

Ravi, T. M. (2011). The Path to Information Management Nirvana. Information Management Daily.

Reddy, G. S., Srinivasu, R., Rikkula, S. R. and Rao, V. S. (2009). Management Information Systems to help Managers for Providing decision making in an Organisation. International Journal of Reviews in Computing, 2076-3336.

Robek, M. F., Brown, G. F., and Stephens, D. O. (1995). Information and Records Management: Document-Based Information Systems (4th Edition ed.). New York, Columbus: Mc Graw-Hill.

Robertson, J. (2005). 10 Principles of Effective Information Management. Step Two Design pty Limited.

Saloojee, R., Groenewald, D., and du Toit, A. S. (2007). Investigating the business value of information management . South African Journal of Information Management.

Sebina, P. M. (2007). Information management in Africa to undergo a change. Assess to Information Network-Africa (ATINA).

Southwest.solution. (n.d.). Southwestsolution.com. Retrieved July 15, 2013, from Information-management solution: http://www.south westsolution.com/markets/information-management-solutions

Stair, R. M. and Reynolds, G. W. (2006). Principles of Information Systems, A Managerial Approach, $\left(7^{\text {th }}\right.$ ed). Boston, Massachusetts: Thomason Learning Inc.

Stamoulis, D., Gouscos, D., Georgiadis, P., and Martakos, D. (2001). Revisiting Public Information Management for Effective egovernment Services. Information Management and Computer Security(Emerald Journals, 9 (4), 146-153.

Stewart, W., Coulson, S., and Wilson, R. (2007). Information Technology: When is it Worth the Investment. Communications of the IIMA, $7(3)$.

Stiroh, K. J. (2001). Investing in Information Technology: Productivity Payoffs for U. S. Industries. Current Issues in Economics and Finance: Federal Reserve Bank of New York. 7 ; (6).

Trauth, E. M. (1989). The Evolution of Information Resource Management . Information and Management 16, 257 - 268.

Tungare, M. (2007). Understanding the Evolution of Users' Personal Information Management Practices. Blacksburg, VA, USA.: Springer Berlin Heidelberg.

Weintraub, A., Owens, L., and Jedinak, E. (2013). The enterprise information management Barbell strengthens your information value. Cambridge M.A. USA: Forrester Research Inc. 